\title{
Adventitious Shoot Regeneration from In Vitro Leaf Explants of the Peach Rootstock Hansen 536
}

\author{
Angela Ricci ${ }^{1}$, Luca Capriotti ${ }^{1}$, Bruno Mezzetti $^{1}\left(\mathbb{D}\right.$, Oriano Navacchi ${ }^{2}$ and Silvia Sabbadini ${ }^{1, * \mathbb{C}}$ \\ 1 Department of Agricultural, Food and Environmental Sciences, Marche Polytechnic University, \\ 60131 Ancona, Italy; angela.ricci@pm.univpm.it (A.R.); l.capriotti@pm.univpm.it (L.C.); \\ b.mezzetti@staff.univpm.it (B.M.) \\ 2 Vitroplant Italia, 47521 Cesena, Italy; orianonavacchi@vitroplant.it \\ * Correspondence: s.sabbadini@staff.univpm.it
}

Received: 23 May 2020; Accepted: 12 June 2020; Published: 16 June 2020

\begin{abstract}
In the present study, an efficient system for the in vitro regeneration of adventitious shoots from the peach rootstock Hansen 536 leaves has been established. Twenty regeneration media containing McCown Woody Plant Medium (WPM) as a basal salt supplemented with different concentrations and combinations of plant growth regulators (PGRs) were tested. Expanded leaves along with their petiole from 3-week-old elongated in vitro shoot cultures were used as starting explants. The highest regeneration rate (up to 53\%) was obtained on WPM basal medium enriched with $15.5 \mu \mathrm{M} \mathrm{N}{ }^{6}$-benzylaminopurine (BAP). The influences on leaf regeneration of the ethylene inhibitor silver thiosulphate (STS) and of different combinations of antibiotics added to the optimized regeneration medium were also investigated. The use of $10 \mu \mathrm{MSTS}$ or carbenicillin $(238 \mu \mathrm{M})$ combined with cefotaxime $(210 \mu \mathrm{M})$ significantly increased the average number of regenerating shoots per leaf compared to the control. In vitro shoots were finally elongated, rooted and successfully acclimatized in the greenhouse. The results achieved in this study advances the knowledge on factors affecting leaf organogenesis in Prunus spp., and the regeneration protocol described looks promising for the optimization of new genetic transformation procedures in Hansen 536 and other peach rootstocks and cultivars.
\end{abstract}

Keywords: Prunus persica; in vitro organogenesis; somatic tissue; STS; carbenicillin; cefotaxime

\section{Introduction}

The genetic improvement of woody fruit species, including peach, through biotechnological approaches is often limited by the lack of tissue culture systems that allow the delivery of desired traits in the plant host genome and by the subsequent regeneration of the selected transgenic lines. Thus, the establishment of efficient in vitro adventitious regeneration methods represents a prerequisite for the development and application of effective transformation procedures aimed to genetically improve perennial crops [1].

Among fruit trees, peach is recognized as one of the most recalcitrant species in terms of in vitro organogenesis [2], and only a few studies report the establishment of efficient and reproducible regeneration protocols starting from different explants of peach rootstocks and cultivars. Although the use of adult tissues is highly recommended to preserve desirable traits of peach selected clones [3], adventitious shoots regeneration starting from seed-derived material has been the main successful approach used in the past for this species [4-8]. However, peach adventitious shoot regeneration, avoiding the use of juvenile tissues, has also been recorded starting from meristematic tissues $[2,3,9]$ and leaves [10-13]. In particular, Gentile et al. (2002) described the only study reporting in vitro shoot organogenesis from leaves of Prunus persica L. cultivars (from expanded leaves, from leaves 
of preconditioned shoot apices and from leaves of adventitious shoots) [10]. Other results showing adventitious shoot regeneration from leaves have been reported for the peach hybrid rootstocks Nemaguard (P. persica $\times$ P. davidiana) [11], Guardian $($ (BY520-9 peach seedling rootstock) [12] and Hansen 536 (P. persica $\times$ P. amygdalus) [13]. These reports show the difficulty in setting up a versatile and efficient protocol for peach leaf organogenesis, which often depends on the genotype selected, and it is highly influenced by the starting explant used, by the macro-/microelements and plant growth regulators (PGRs) composing the basal culture medium and by the exposure to different hours/weeks of darkness/light during explant in vitro cultures. Furthermore, several studies describe how the accumulation of ethylene during in vitro tissue culture can have a negative impact on shoot regeneration (reviewed by Biddington [14]). Silver thiosulfate (STS), an ethylene inhibitor [15], has been successfully utilized as the promoter of adventitious shoot regeneration from leaf tissues of $P$. armenica L. [16], P. serotina Ehrh. [17] and P. domestica L. [18]. The only report investigating the effect of STS on shoot regeneration from peach leaf explants is reported by San et al. [12], where a regeneration rate of $16 \%$ of the peach rootstock Guardian@is reported.

As reported by several authors, the development of efficient protocols for shoot regeneration starting from somatic tissues of peach rootstocks is one of the primary objectives required for the application of gene-delivery technologies to this recalcitrant fruit crop [11-13,19]. In fact, peach rootstocks, such as peach $\times$ almond hybrids, have been extensively used for the propagation of peach plants, given their favourable agronomic traits, such as high tolerance to calcareous and dry soils, good productivity induced in the grafted peach scion, and resistance to several plant pathogens and pests [19-21]. Among peach $\times$ almond hybrid rootstocks, Hansen 536 (P. persica $\times$ P. amygdalus) has been used for grafting both peach and almond genotypes and has reached a significant commercial importance especially in California [13]. It is characterized by a high plant vigour also in poor and alkaline soils and shows resistance against some root-knot nematodes (M. arenaria, $M$. incognita and $M$. javanica) $[19,22,23]$. However, this genotype needs further genetic improvement especially due to its low waterlogging tolerance, which prevents its spread also in other geographical area $[13,19]$.

In a recent paper, we described the optimization of an in vitro regeneration and transformation protocol for the peach hybrid rootstock Hansen 536 (P. persica $\times$ P. amygdalus) using meristematic bulks as starting explants [3]. Even though the regeneration rate obtained through this system was about $80 \%$, only transgenic callus lines were obtained that did not lead to the regeneration of any transgenic plant. One possible solution to this bottleneck can be the development and use of a different regeneration protocol from somatic tissues, more suitable to obtain Hansen 536 transgenic plants in future transformation trials. The present study aimed to establish the optimal conditions necessary to induce an efficient organogenetic response from in vitro Hansen 536 leaf explants by evaluating the effect of different PGRs concentrations and combinations added to the basal regeneration medium. Furthermore, the impact of different compounds that could significantly enhance adventitious shoot regeneration efficiency was evaluated. In particular, we studied the influence of STS on Hansen 536 shoot regeneration as well as the effect on the regeneration efficiency of different antibiotics, which are often used in genetic transformation systems to contain Agrobacterium overgrowth. The established protocol represents a useful tool for the optimization of new genetic transformation methods and for the application of biotechnological approaches aimed at improving genetically Hansen 536 and other peach rootstocks and varieties.

\section{Results}

\subsection{Influence of Different Combinations and Concentrations of PGRs on Regeneration Efficiency from} Leaf Explants

Twenty regeneration media (WPM 1-WPM 20) supplemented with different concentrations and combinations of PGRs were tested to evaluate the organogenetic competence and adventitious shoot regeneration efficiency of Hansen 536 leaf explants (Table 1). Three weeks after incubation in dark condition, calli appeared on petioles and formed around the cuts made perpendicular to the 
leaf mid vein, and some buds and adventitious shoots started to regenerate, mainly on the petiole surface. After five weeks of culture, about $100 \%$ caulogenesis was observed on leaves cultured on most of the tested regeneration media (except for WPM 1, where no caulogenesis was recorded) (data not shown). Differences were observed for callus size based on the PGR combination used (Supplementary Figure S1). Data acquired after five weeks from the beginning of the trial revealed higher values of both regeneration frequency and average number of regenerating shoots per leaf when the explants were cultured on basal medium supplemented with different concentrations of $\mathrm{N}^{6}$-benzylaminopurine (BAP) used alone or in combination with $0.25 \mu \mathrm{M} \alpha$-naphtalene acetic acid (NAA) (Table 1). In particular, the highest regeneration frequency and mean number of regenerating shoots per leaf, $53 \%$ and $0.77 \pm 0.08$, respectively, were obtained from explants cultured on medium containing $15.5 \mu \mathrm{M}$ BAP alone (WPM 11), whereas the analysis of results obtained by using different cytokinins other than BAP in the basal medium, like kinetin (KIN) or thidiazuron (TDZ), showed a significant decrease in the organogenetic response of leaf explants, with regeneration rates up to $13 \%$ and 28\% for WPM 6 and WPM 15, respectively. Furthermore, the combined use of NAA together with TDZ in the media seemed to have a negative influence on adventitious shoot regeneration compared to the use of TDZ alone (Table 1).

Table 1. Influence of plant growth regulators (PGRs) on the regeneration efficiency from Hansen 536 leaf (LF) explants cultured for five weeks on regeneration media.

\begin{tabular}{|c|c|c|}
\hline Regeneration Media & Frequency of Regeneration $(\%) \pm S E *$ & Average Number of Regenerating Shoots/LF $\pm \mathrm{SE}$ \\
\hline WPM 1 & 0 (g) & $0^{(\mathrm{e})}$ \\
\hline WPM 2 & $0^{(\mathrm{g})}$ & $0^{(\mathrm{e})}$ \\
\hline WPM 3 & $8.7 \pm 2.3^{(\mathrm{fg})}$ & $0.12 \pm 0.03^{(\mathrm{de})}$ \\
\hline WPM 4 & $9.3 \pm 2.38^{(\mathrm{fg})}$ & $0.11 \pm 0.04$ (de) \\
\hline WPM 5 & $6.7 \pm 2.04(\mathrm{fg})$ & $0.07 \pm 0.02$ (de) \\
\hline WPM 6 & $13.3 \pm 2.78^{(\mathrm{defg})}$ & $0.15 \pm 0.03$ (cde) \\
\hline WPM 7 & $3.3 \pm 1.47(\mathrm{~g})$ & $0.03 \pm 0.0 .1^{(\mathrm{e})}$ \\
\hline WPM 8 & $2 \pm 1.15(\mathrm{~g})$ & $0.02 \pm 0.01(\mathrm{e})$ \\
\hline WPM 9 & $26.7 \pm 3.62^{(\mathrm{bcd})}$ & $0.41 \pm 0.06^{(b)}$ \\
\hline WPM 10 & $24.7 \pm 3.53^{\text {(bcde) }}$ & $0.39 \pm 0.06^{(b)}$ \\
\hline WPM 11 & $53 \pm 4.02$ (a) & $0.77 \pm 0.08$ (a) \\
\hline WPM 12 & $29.3 \pm 3.73^{(b c)}$ & $0.47 \pm 0.07^{(b)}$ \\
\hline WPM 13 & $32 \pm 3.82(\mathrm{bc})$ & $0.39 \pm 0.05^{(b)}$ \\
\hline WPM 14 & $37 \pm 3.84^{(b)}$ & $0.48 \pm 0.06^{(b)}$ \\
\hline WPM 15 & $28 \pm 3.88^{(b c)}$ & $0.48 \pm 0.06^{(b)}$ \\
\hline WPM 16 & $20 \pm 3.59$ (cdef) & $0.3 \pm 0.06^{(\mathrm{bcd})}$ \\
\hline WPM 17 & $24 \pm 3.49^{\text {(bcde) }}$ & $0.36 \pm 0.07(b c)$ \\
\hline WPM 18 & $12 \pm 3.19(\mathrm{efg})$ & $0.16+0.05$ (de) \\
\hline WPM 19 & $2 \pm 2.72(\mathrm{~g})$ & $0.02 \pm 0.04(\mathrm{e})$ \\
\hline WPM 20 & $6 \pm 2.04(\mathrm{fg})$ & $0.06 \pm 0.03^{(\mathrm{de})}$ \\
\hline
\end{tabular}

${ }^{*}$ Number of explants regenerating at least one shoot per total explants treated $\times 100$. One-way ANOVA was used to analyse the results. Different letters in the same column show significant differences at $p<0.05$ by the Newman-Keuls test \pm SE $(n=150)$. Each value represents the mean \pm SE of three independent experiments. WPM, McCown Woody Plant Medium.

\subsection{Influence of Silver Thiosulphate on Regeneration Efficiency from Leaf Explants}

The effect of silver thiosulphate (STS) supplemented in WPM 11 medium on shoot organogenesis from Hansen 536 leaf explants was evaluated after five weeks of culture (Figure 1a,b). STS did not increase explant regeneration frequency at any of the concentrations tested. The highest value (50\%) was obtained by adding $10 \mu \mathrm{M}$ STS to the regeneration medium, and it was not significantly different to the regeneration frequency observed from leaves placed on regeneration medium without STS (47\%) (Figure 1a), whereas the average number of regenerating shoots per leaf increased two-fold (a mean of $1.14 \pm 0.13$ shoots per explant) when STS was used at a concentration of $10 \mu \mathrm{M}$ compared to the control (a mean of $0.61 \pm 0.08$ shoots per explant) (Figure $1 \mathrm{~b}-\mathrm{d}$ ). Concentrations of STS higher than $10 \mu \mathrm{M}$ inhibited adventitious shoot regeneration progressively; in particular, when STS was used at 20, 
40 or $80 \mu \mathrm{M}$, the regeneration frequency decreased drastically to $29.3 \%, 20 \%$ and $5.3 \%$, respectively (Figure 1a), while the average number of regenerating shoots per leaf decreased significantly by using a concentration of STS equal or higher than $40 \mu \mathrm{M}$ (Figure 1b). Furthermore, when STS was added to the regeneration medium at any concentration tested, we observed a higher frequency of shoots that also regenerated on the cuts made perpendicular to the leaf mid vein (Figure 1e), while most of the shoots regenerated only on petiole surface when explants were cultured without STS (data not shown).
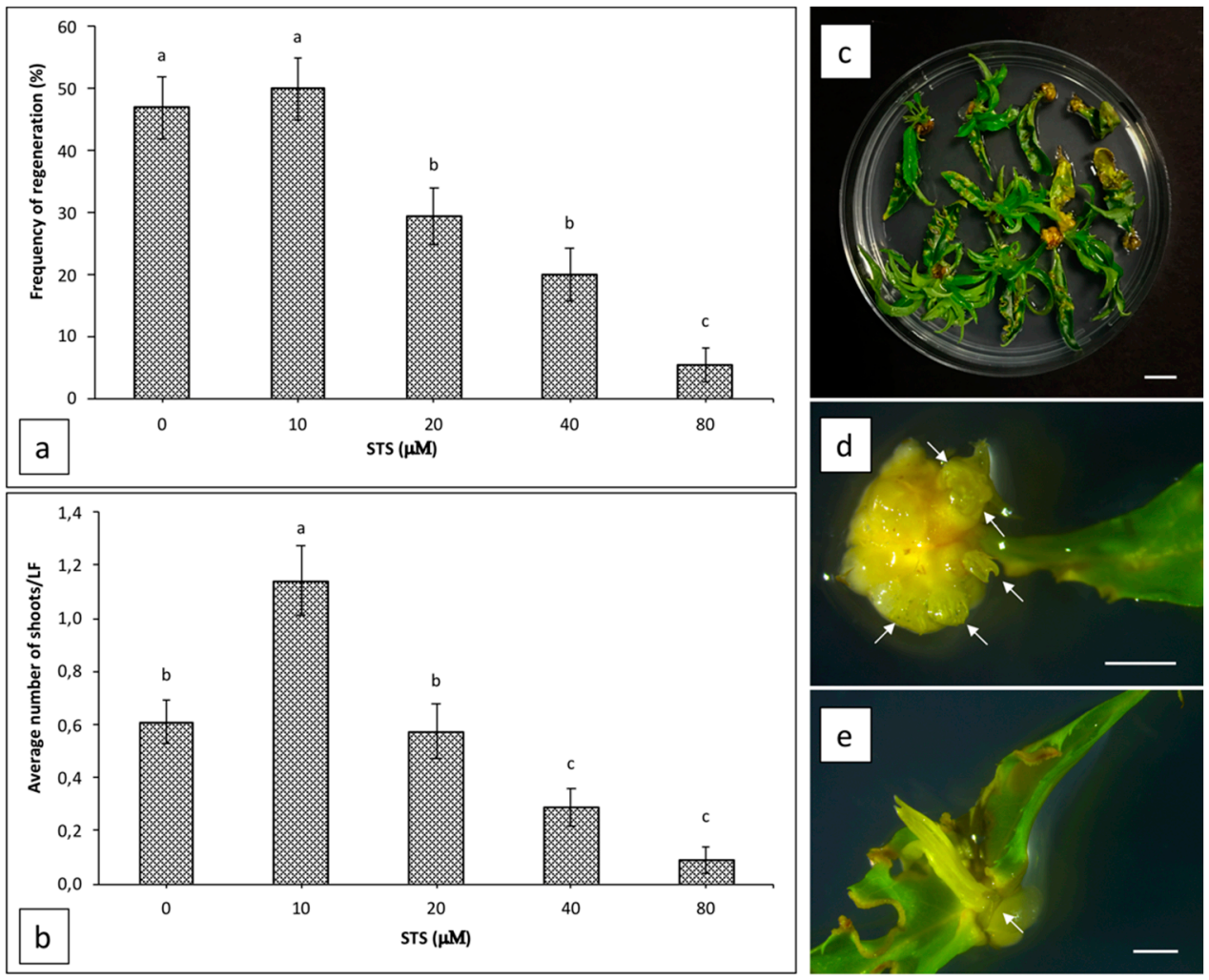

Figure 1. Regeneration efficiency of Hansen 536 leaf explants cultured on WPM 11 supplemented with different concentrations of silver thiosulphate (STS): (a) frequency of regeneration expressed as the number of explants regenerating at least one shoot per total explants treated $\times 100$ and (b) the average number of regenerating shoots per leaf (LF) after five weeks of culture. One-way ANOVA was used to analyse the results. Different letters show significant differences at $p<0.05$ by the Newman-Keuls test \pm SE $(n=150)$. Each value represents the mean \pm SE of three independent experiments. (c) Adventitious shoots regenerating from leaf explants after seven weeks of culture on WPM 11 supplemented with $10 \mu \mathrm{M}$ STS (bar $=1 \mathrm{~cm}$ ). Adventitious shoots regenerating from petiole (d) and from cuts perpendicular to the leaf mid vein (e) of Hansen 536 leaves after three weeks of culture on WPM 11 supplemented with $10 \mu \mathrm{M}$ STS (bar = $2 \mathrm{~mm}$ ). White arrows indicate regenerating adventitious shoots.

\subsection{Influence of Antibiotics on Regeneration Efficiency from Leaf Explants}

The effect of different antibiotics added to WPM 11 medium on adventitious shoot regeneration efficiency of Hansen 536 leaves was observed after five weeks of culture (Table 2). Similar to the results obtained when STS was supplemented in the basal regeneration medium, the addition of antibiotics also did not significantly increase the regeneration frequency of leaf explants compared to the control. However, the addition of carbenicillin $(238 \mu \mathrm{m})$ plus cefotaxime $(210 \mu \mathrm{m})$ in the WPM 11 medium positively affected the average number of regenerating shoots per leaf compared to the control and to the other antibiotics tested (Table 2). On the contrary, when the same antibiotics were applied alone at higher concentrations, regeneration rates decreased more than two-fold. 
Table 2. Effect of antibiotics on the regeneration efficiency from Hansen 536 leaf (LF) explants cultured for five weeks on WPM 11 medium.

\begin{tabular}{|c|c|c|c|}
\hline Antibiotic(s) ${ }^{w}$ & $\mu \mathbf{M}^{\mathrm{y}}$ & $\begin{array}{c}\text { Frequency of } \\
\text { Regeneration }(\%) \pm \mathrm{SE}^{\mathrm{z}}\end{array}$ & $\begin{array}{c}\text { Average Number of } \\
\text { Regenerating Shoots } / \mathrm{LF} \pm \mathrm{SE}\end{array}$ \\
\hline None & 0 & $49 \pm 5.02$ (a) & $0.61 \pm 0.08^{(b)}$ \\
\hline Carbenicillin & 475 & $19.3 \pm 3.68^{(b)}$ & $0.4 \pm 0.07^{(\mathrm{bc})}$ \\
\hline Cefotaxime & 420 & $21.4 \pm 3.86^{(b)}$ & $0.33 \pm 0.06^{(b c)}$ \\
\hline Timentin $^{x}$ & 514 & $9.3 \pm 1.41^{(b)}$ & $0.17 \pm 0.01^{(\mathrm{c})}$ \\
\hline Carbenicillin/Cefotaxime & $238 / 210$ & $43 \pm 4.94^{(a)}$ & $0.91 \pm 0.13^{(a)}$ \\
\hline Timentin/Cefotaxime & $171 / 210$ & $21.3 \pm 3.94^{(b)}$ & $0.39 \pm 0.07^{(b c)}$ \\
\hline
\end{tabular}

${ }^{\mathrm{w}}$ Duchefa Biochemie, Haarlem, The Netherlands. ${ }^{\mathrm{x}} 15: 1$ mixture of ticarcillin and clavulanic acid. ${ }^{\mathrm{y}}$ Common concentrations found in the literature to control Agrobacterium growth. ${ }^{\mathrm{z}}$ Number of explants regenerating at least one shoot per total explants treated $\times 100$. One-way ANOVA was used to analyse the results. Different letters in the same column show significant differences at $p<0.05$ by the Newman-Keuls test $\pm \mathrm{SE}(n=150)$. Each value represents the mean $\pm \mathrm{SE}$ of three independent experiments.

\subsection{In Vitro Rooting and Acclimatization of Adventitious Shoots}

Adventitious shoots developed in the above treatments were in vitro elongated, rooted, and acclimatized. About $85 \%$ of them were able to produce in vitro roots (about $0.5-1 \mathrm{~cm}$ long) after 20 days in the rooting medium (Figure $2 \mathrm{a}, \mathrm{b}$ ), and about $90 \%$ of them were successfully acclimatized to the greenhouse (Figure 2c).

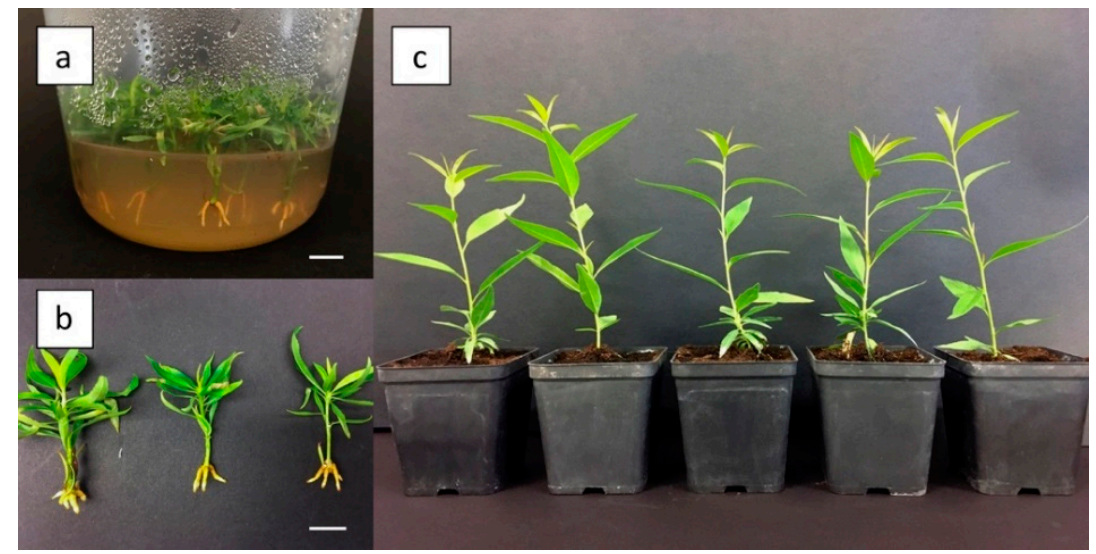

Figure 2. In vitro rooting and acclimatization of adventitious shoots from Hansen 536 leaves: $(\mathbf{a}, \mathbf{b})$ elongated and rooted in vitro adventitious shoots ready for acclimatization and (c) acclimatized rooted shoots in $7 \times 7 \mathrm{~cm}$ pots.

\section{Discussion}

Efficient adventitious shoot regeneration, rooting, and acclimatization were achieved in this study by using leaves of the peach $\times$ almond hybrid rootstock Hansen 536 as the starting plant material. One of the most important factors affecting plant tissue regeneration is the type and concentrations of PGRs added to the regeneration medium. In this study, the highest regeneration efficiency $(53 \%$, with mean number of shoots per explant of $0.77 \pm 0.08$ ) was obtained when WPM basal medium was enriched with $15.5 \mu \mathrm{M}$ BAP (WPM 11), albeit good regeneration rates (from $29.3 \%$ up to $37 \%$ ) were also obtained when explants were placed on media supplemented with BAP in combination with NAA. Similarly, Gentile et al. [10], reporting in vitro shoot induction from P. persica leaves, showed that the best results were obtained from leaves when BAP was used as cytokinin in the media; the highest shoot regeneration rate of $28.3 \%$ was recorded in peach cv. 842 Standard. Furthermore, Zong et al. [13] have recently optimized a protocol for Hansen 536 in vitro leaf regeneration, which led to a maximum shoot 
regeneration rate of $36.1 \%$ when explants were cultured on WPM media supplemented with BAP in combination with indole-3-butyric acid IBA, confirming the positive influence conferred by the use of BAP as a cytokinin on leaf organogenesis from peach. However, other studies have reported better results on peach leaf regeneration when cytokinins other than BAP were added to the culture medium. As observed by Zhou et al. [11], leaves of the peach rootstock Nemaguard induced the best regeneration of shoots $(71.7 \%$, with mean number of shoots of $5.74 \pm 3.24)$ when cultured in the presence of TDZ as cytokinin $(9.08 \mu \mathrm{M}$ TDZ $+0.54 \mu \mathrm{M}$ IBA). Additionally, San et al. [12] observed a positive effect conferred by the use of TDZ instead of BAP as a cytokinin for shoot regeneration from Guardian ${ }^{\circledR}$ in vitro leaves. However, in this study, the presence of TDZ combined with NAA was not sufficient to induce shoot organogenesis, but the addition of the ethylene inhibitor STS at a concentration of $10 \mu \mathrm{M}$ was an essential factor to obtain an organogenetic response (regeneration rate of $16 \%$ with a mean number of shoots of 1.6). Our results showed that the use of TDZ induced a significant reduction in the regeneration of shoots from Hansen 536 leaves compared to WPM 11 medium, especially when TDZ was used in combination with NAA in the regeneration media. Similarly, in our study, the regeneration rates obtained by the use of KIN as a cytokinin were significantly lower $(13.3 \%$ of regeneration) compared to the use of BAP alone; however, to our knowledge, this represents the first successful attempt to induce adventitious regeneration from peach leaves through the use of KIN. Indeed, other authors reported the effect of KIN on caulogenesis from peach leaves, which did not lead to the regeneration of any adventitious shoot [24,25]. Although all the studies mentioned above underline the difficulty in obtaining a versatile protocol to be applied for leaf organogenesis in different peach genotypes, it seems that the presence of the petiole as part of the starting leaf explant represents a critical factor for a successful adventitious shoot regeneration from leaves of peach rootstocks and cultivars, as also reported by Gentile et al. [10] and by other authors in different Prunus species [17,25,26]. Indeed, in all these studies, including ours, most of the regenerated adventitious shoots were observed at the petiole. Several studies carried out on Prunus spp. have also demonstrated that the interaction among different factors, other than the medium composition, concur in the organogenetic response of in vitro leaf explants, such as plant source conditions, the age of explant, cut side and leaf orientation on the culture substrate $[11,27]$. In our study, we observed a very low frequency of leaf organogenesis when Hansen 536 explants were cultured with the adaxial surface in contact with WPM11 medium (Supplementary Figure S2; data not shown) in contrast with the results obtained by Zong et al. on the same genotype [13] and by Gentile et al. on peach cultivars [10]. Several authors have examined the influence of leaf orientation on explant regeneration frequency in different plant species, however without obtaining a common response [27-32]. In general, it seems that a higher regeneration efficiency should be achieved when the wounded surface of the leaf is in contact with the medium, probably due to a better absorption of nutrients and PGRs from the substrate $[27,33]$. Furthermore, the different organogenetic responses of the leaf in its two different orientations can be connected to the total surface area that is in contact with the substrate. Positioning the abaxial side of the explant on the medium avoids the typical curling of both ends of the leaf that occurs when it is oriented with the adaxial surface on the substrate $[28,31]$.

In the present study, we also investigated the influence of different concentrations of STS supplemented in the culture medium on the regeneration frequency and mean number of shoots from Hansen 536 leaves. Different authors stated that STS has a positive role in shoot organogenesis from leaf tissues of Prunus spp., including peach $[12,16,18]$. This effect seems to be associated to the action of $\mathrm{Ag}^{+}$ions present in this compound, which block ethylene signal transduction induced by in vitro cultured explants [16]. The ability of $\mathrm{Ag}^{+}$ions to inhibit ethylene action seems to prevent some of its negative effect during shoots organogenesis [34,35]. In our study, we observed a significant increase in the average number of shoots per explant when STS was used at a concentration of $10 \mu \mathrm{M}$. Furthermore, the effect of this ethylene inhibitor on Hansen 536 leaf organogenesis was dose-dependent; in particular, when STS was used at concentrations higher than $10 \mu \mathrm{M}$, adventitious shoot regeneration was progressively inhibited. Our results together with previously published data reported by San 
and collaborators [12] suggest $10 \mu \mathrm{M}$ as the optimal concentration of STS capable of improving the adventitious regeneration of peach leaves. Other studies have already reported that STS and similar compounds, like silver nitrate, are biologically active at very low concentrations for some plant species [34,36]; in these cases, if the maximum effective concentration of STS is reached, toxic effects on plant tissues are induced and regeneration responses are inhibited, as also observed in our study. This also suggests that, at the right level, the presence of ethylene in the tissue culture is still needed for an efficient organogenetic response, as also reported by other studies [37,38]. Thus, as remarked by Petri and Scorza [18], the optimum STS concentration in Prunus spp. and other plant species is often genotype-dependent, making essential the evaluation of STS impact on shoot regeneration from each cultivar or rootstock.

Lastly, the influence of different antibiotics included in the WPM 11 medium on the regeneration efficiency from Hansen 536 leaves was evaluated; this trial aimed to test only the antibiotics commonly used during Agrobacterium-mediated transformation trials to avoid bacterial persistence in the medium post-transformation. Several studies reported the positive effect of antibiotics on organogenetic processes in different plant species included Prunus spp. [16,39-51]. We observed that carbenicillin $(238 \mu \mathrm{M})$ combined with cefotaxime $(210 \mu \mathrm{M})$ improved the average number of shoots per explant compared to the control, whereas the same antibiotics used alone at higher concentrations decreased regeneration efficiency (Table 2). Carbenicillin has been often tested to improve plant organogenesis, and it seems that the positive effect reported by different studies can be related to the byproducts released during its breakdown, which show an auxin-like activity with beneficial effects on shoot development in various plant species [16,39,44-48]. In our study, a concentration of carbenicillin higher than $238 \mu \mathrm{M}$ has probably induced an excess in auxin activity in peach leaf tissues, which led to a considerable reduction of regeneration frequency from Hansen 536 leaves. Similarly, a toxic effect of this antibiotic used at concentrations higher than $238 \mu \mathrm{M}$ was also observed by other authors working with different plant species other than Prunus spp. [49,52,53]. Differently from carbenicillin, the chemical conformation of cefotaxime does not suggest the production of auxin-like compounds as byproducts during its breakdown [48,54]; thus, additional studies are needed to understand the mode of action of this antibiotic and its involvement in plant metabolism. Our results show that the use of cefotaxime at concentrations higher than $210 \mu \mathrm{M}$ leads to a reduction in regeneration efficiency; the negative effect of cefotaxime on plant organogenesis has also been reported in other studies $[48,52,55]$, even though the neutral or beneficial impacts of this antibiotic on morphogenesis of several plant species [39-42,46,49-51,56], including Prunus spp. [16], have been the main outcome observed until date.

In conclusion, we set up a valid and reproducible adventitious shoot regeneration system from Hansen 536 leaf tissues with a frequency up to $53 \%$ when explants were cultured on WPM medium enriched with $15.5 \mu \mathrm{M}$ BAP. The established protocol has improved the regeneration efficiency of Hansen 536 leaves compared with maximum results reported by Zong et al. [13] (regeneration frequency up to $36 \%$ ) on the same genotype, probably due to the interaction of different factors, such as different sources of starting plant material, medium composition, leaf orientation on the substrate and type of leaf incision. Furthermore, we identified the optimal concentration of STS which significantly improved shoot regeneration by increasing two-fold the average number of shoots per explant. In addition, the regeneration medium enriched with carbenicillin combined with cefotaxime at the concentration tested induced a significant increase of regenerating shoots per leaf. This result has particular relevance for the genetic transformation of this peach genotype. In fact, these kinds of antibiotics are normally used during genetic transformation processes to contain Agrobacterium persistence in the medium after transforming plant tissues; therefore, it is essential to avoid negative effects on regeneration efficiency that could be caused by these compounds [16]. The overall results obtained in this study should improve the knowledge on factors controlling peach leaf organogenesis, and the results achieved by the best combination of the tested factors look promising for the optimization of new genetic transformation protocols in Hansen 536 and other peach rootstocks and cultivars. 


\section{Materials and Methods}

\subsection{Establishment of In Vitro Shoots}

Shoot tips (approximately $0.5 \mathrm{~cm}$ long) were cut from 10-cm-long shoots of 10-year-old greenhouse-grown peach $\times$ almond hybrid rootstock Hansen 536 (P. persica $\times$ P. amygdalus) trees at Vitroplant Italia, Cesena, Italy and used to establish peach in vitro cultures. The collected shoot tips were surface sterilized by washing them in 1\% (V/V) sodium hypochlorite solution for 15 min, followed by three washes with sterile distilled water. Explants were then placed on shoot multiplication medium composed of McCown Woody Plant Medium (WPM) (Duchefa Biochemie, Haarlem, The Netherlands) basal salts and vitamins [57], $30 \mathrm{~g} \mathrm{~L}^{-1}$ sucrose and $5 \mathrm{~g} \mathrm{~L}^{-1}$ plant agar S1000 (B\&V, Reggio Emilia, Italy) [3] supplemented with 6.6 $\mu \mathrm{M} \mathrm{N}^{6}$-benzylaminopurine (BAP) (Duchefa Biochemie, Haarlem, The Netherlands) and $0.1 \mu \mathrm{M} \alpha$-naphtalene acetic acid (NAA) (Duchefa Biochemie, Haarlem, The Netherlands). The final $\mathrm{pH}$ value was adjusted to 5.7 with $\mathrm{KOH}$ before autoclaving at $121^{\circ} \mathrm{C}$ for $20 \mathrm{~min}$. In vitro cultures were kept in a growth chamber at $24 \pm 1{ }^{\circ} \mathrm{C}$ under a photoperiod of 16 -h light $\left(70 \mu \mathrm{mol} / \mathrm{m}^{2} / \mathrm{s}\right)$ provided by white fluorescent tubes, and they were periodically subcultured (2-week intervals) on fresh shoot multiplication medium for a total of three subcultures. Proliferating shoots were then transferred to the elongation medium in order to provide expanded leaves for this study. Preparation and composition of the elongation medium were the same as for the shoot multiplication medium, except for plant growth regulators (PGRs) concentrations, corresponding to $0.45 \mu \mathrm{M}$ BAP and $0.1 \mu \mathrm{M}$ NAA. In vitro shoots were maintained on the elongation medium for 20 days at the same light and temperature conditions as described above and then used for shoot regeneration trials.

\subsection{General Approach for Adventitious Shoot Regeneration}

The first four apical expanding leaves (about 1.5-2 cm in length) along with their petiole from 3-week-old elongated shoot cultures were used as starting explants in this study (Figure 3a). The abaxial surface of each leaf was wounded about four times at each side perpendicular to the leaf mid vein, leaving the sections intact, and then placed with the abaxial side in contact with the regeneration medium (Figure 3b,c). Leaves were cultured on WPM basal salts and vitamins, $30 \mathrm{~g} \mathrm{~L}^{-1}$ sucrose and $5 \mathrm{~g} \mathrm{~L}^{-1}$ plant agar S1000 (B\&V, Reggio Emilia, Italy); the $\mathrm{pH}$ was adjusted to 5.7 before autoclaving at $121^{\circ} \mathrm{C}$ for $20 \mathrm{~min}$, and then $25 \mathrm{~mL}$ of medium was poured into sterile plastic Petri dishes $(9 \mathrm{~cm} \times 1.5 \mathrm{~cm})$. After leaves were placed on medium, the dishes were maintained in darkness at $24 \pm 1^{\circ} \mathrm{C}$ for three weeks. In vitro leaves were then transferred to fresh media and exposed to light (16-h photoperiod at a light intensity of $40 \mu \mathrm{mol} / \mathrm{m}^{2} / \mathrm{s}$ ) at $24 \pm 1^{\circ} \mathrm{C}$. Data on the leaf regeneration frequency and on the average number of regenerating shoots per leaf were collected after five weeks from the beginning of the trial.

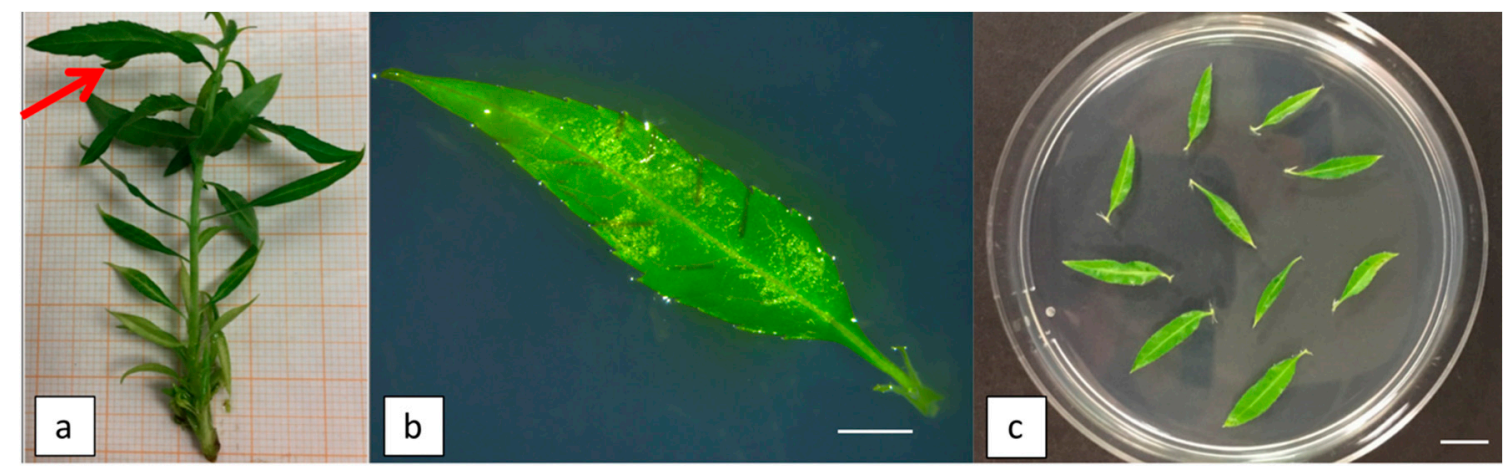

Figure 3. Plant material used as the starting explants in this study: (a) leaves collected from 3-week-old elongated shoots of Hansen 536. The arrow indicates the type of leaf collected and used in all the regeneration experiments; (b) the young leaf of the Hansen 536 wounded perpendicular to the mid vein and placed with the abaxial side on regeneration medium (bar $=2 \mathrm{~mm}$ ), and (c) in vitro leaves of Hansen 536 placed on regeneration medium (bar $=1 \mathrm{~cm}$ ). 


\subsection{Effect of Different Combinations and Concentrations of PGRs}

In this experiment, leaves were placed on regeneration media supplemented with cytokinins, as kinetin (KIN) (Duchefa Biochemie, Haarlem, The Netherlands) (14, 16.3 or $19 \mu \mathrm{M}), \mathrm{BAP}(11,13.3$ or $15.5 \mu \mathrm{M}$ ) or thidiazuron (TDZ) (Duchefa Biochemie, Haarlem, The Netherlands) $(2.25,4.5$ or $9 \mu \mathrm{M}$ ) and with auxin, as NAA $(0.25 \mu \mathrm{M})$, for a total of 20 different media combinations (Table 3).

Table 3. Different concentrations and combinations of PGRs used in the regeneration medium.

\begin{tabular}{lcccc}
\hline & \multicolumn{4}{c}{ Plant Growth Regulators $(\mu \mathrm{M})$} \\
\cline { 2 - 5 } & KIN & BAP & TDZ & NAA \\
\hline WPM 1 & - & - & - & - \\
WPM 2 & - & - & - & 0.25 \\
WPM 3 & 14 & - & - & - \\
WPM 4 & 16.3 & - & - & - \\
WPM 5 & 19 & - & - & - \\
WPM 6 & 14 & - & - & 0.25 \\
WPM 7 & 16.3 & - & - & 0.25 \\
WPM 8 & 19 & - & - & 0.25 \\
WPM 9 & - & 11 & - & - \\
WPM 10 & - & 13.3 & - & - \\
WPM 11 & - & 15.5 & - & - \\
WPM 12 & - & 11 & - & 0.25 \\
WPM 13 & - & 13.3 & - & 0.25 \\
WPM 14 & - & 15.5 & - & 0.25 \\
WPM 15 & - & - & 2.25 & - \\
WPM 16 & - & - & 4.5 & - \\
WPM 17 & - & - & 9 & - \\
WPM 18 & - & - & 2.25 & 0.25 \\
WPM 19 & - & - & 4.5 & 0.25 \\
WPM 20 & - & - & 9 & 0.25 \\
\hline W6-bory
\end{tabular}

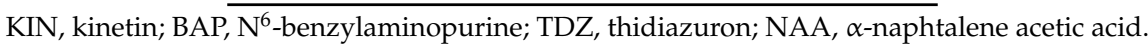

\subsection{Effect of Silver Thiosulphate}

Young expanding leaves were placed on WPM 11 regeneration medium supplemented with different concentrations of silver thiosulphate (STS) $(0,10,20,40$ or $80 \mu \mathrm{M})$. Preparation of media and culture conditions of the leaves were the same as previously described.

Stock solutions $(0.1 \mathrm{M})$ of sodium thiosulphate and silver nitrate were prepared by dissolving $790 \mathrm{mg}$ of sodium thiosulphate (Sigma-Aldrich, Milan, Italy) and $850 \mathrm{mg}$ of silver nitrate (Sigma-Aldrich, Milan, Italy) into $50 \mathrm{~mL}$ of ultrapure water. STS stock solution $(0.02 \mathrm{M})$ was then prepared just before use by slowly adding $20 \mathrm{~mL}$ of silver nitrate stock solution $(0.1 \mathrm{M})$ into $80 \mathrm{~mL}$ of sodium thiosulphate stock solution $(0.1 \mathrm{M})$ (1:4 ratio). STS stock solution was filter-sterilised and added to the medium after autoclaving and cooling down to $50{ }^{\circ} \mathrm{C}$.

\subsection{Effect of Antibiotics}

The influence of different antibiotics added to the WPM 11 medium, alone or combined (Table 2), on the regeneration of Hansen 536 leaves was evaluated using the same regeneration protocol previously reported. Filter-sterilised antibiotics were added to the regeneration medium after autoclaving and cooling down to $50^{\circ} \mathrm{C}$.

\subsection{Shoots Elongation, Rooting and Acclimatization}

Shoots $(1 \mathrm{~cm}$ in length) regenerated from leaf explants in the above experiments were excised and propagated on WPM medium, $30 \mathrm{~g} \mathrm{~L}^{-1}$ sucrose and $5 \mathrm{~g} \mathrm{~L}^{-1}$ plant agar S1000 (B\&V, Reggio 
Emilia, Italy) supplemented with $6.6 \mu \mathrm{M}$ BAP and $0.1 \mu \mathrm{M}$ NAA for a total of three subcultures (2-week intervals). Single shoots were then placed on WPM medium supplemented with $0.5 \mu \mathrm{M}$ BAP and $7.38 \mu \mathrm{M}$ indole-3-butyric acid (IBA) (Duchefa Biochemie, Haarlem, The Netherlands) for 20 days to induce rooting. Shoot cultures were placed in the growth chamber under a photoperiod of $16-\mathrm{h}$ light $\left(70 \mu \mathrm{mol} / \mathrm{m}^{2} / \mathrm{s}\right)$ provided by white fluorescent tubes. In vitro rooted shoots were finally acclimatized in pots $(7 \times 7 \mathrm{~cm})$ containing commercial peat and grown in the greenhouse.

\subsection{Statistical Analysis}

For each treatment included in the regeneration experiments described above, five petri dishes were prepared and a total of fifty explants were used (ten leaves per dish). Three independent experiments were carried out for each regeneration trial. Regeneration frequency is expressed as (number of explants regenerating at least one shoot/total explants treated) $\times 100$. Data on percent regeneration were transformed by the arcsine square root transformation, ARSIN (SQRT (X)), before analysis. Shoot numbers are shown as the mean \pm SE of the total number of shoots regenerating from starting leaves.

The results acquired were analyzed by one-way ANOVA using Statistica 7 software (Statsoft Tulsa, CA, USA), and means were separated using the Newman-Keuls test $(p<0.05)$.

Supplementary Materials: The following are available online at http://www.mdpi.com/2223-7747/9/6/755/s1, Figure S1: Caulogenesis and leaf regeneration from Hansen 536 explants. Figure S2: Hansen 536 leaf explants cultured with the abaxial or adaxial sides on regeneration medium.

Author Contributions: Conceptualization, S.S.; methodology, S.S. and O.N.; validation, S.S. and A.R.; formal analysis, L.C.; investigation, A.R., L.C. and S.S; resources, B.M. and O.N.; data curation, S.S., A.R. and L.C; writing-original draft preparation, A.R.; writing - review and editing, S.S., B.M. and L.C.; visualization, S.S. and A.R.; supervision, S.S. and B.M.; project administration, B.M.; funding acquisition, B.M. All authors have read and agreed to the published version of the manuscript.

Funding: Our study described here was supported by New Plant, Italy and Vitroplant Italia, Italy. We acknowledge the COST-iPLANTA project supported by the European Union's Horizon 2020 research and innovation program under grant agreement CA15223.

Conflicts of Interest: The authors declare that the research was conducted in the absence of any commercial or financial relationships that could be construed as a potential conflict of interest.

\section{References}

1. Xu, S.; Lai, E.; Zhao, L.; Cai, Y.; Ogutu, C.; Cherono, S.; Han, Y.; Zheng, B. Development of a fast and efficient root transgenic system for functional genomics and genetic engineering in peach. Sci. Rep. 2020, 10, 2836. [CrossRef] [PubMed]

2. Pérez-Jiménez, M.; Carrillo-Navarro, A.; Cos-Terrer, J. Regeneration of peach (Prunus persica L. Batsch) cultivars and Prunus persica $\times$ Prunus dulcis rootstocks via organogenesis. Plant Cell Tissue Organ Cult. 2012, 108, 55-62. [CrossRef]

3. Sabbadini, S.; Ricci, A.; Limera, C.; Baldoni, D.; Capriotti, L.; Mezzetti, B. Factors Affecting the Regeneration, via Organogenesis, and the Selection of Transgenic Calli in the Peach Rootstock Hansen 536 (Prunus persica $\times$ Prunus amygdalus) to Express an RNAi Construct against PPV Virus. Plants 2019, 8, 178. [CrossRef] [PubMed]

4. Hammerschlag, F.A.; Bauchan, G.; Scorza, R. Regeneration of peach plants from callus derived from immature embryos. Theor. Appl. Genet. 1985, 70, 248-251. [CrossRef] [PubMed]

5. Bhansali, R.R.; Driver, J.A.; Durzan, D.J. Rapid multiplication of adventitious somatic embryos in peach and nectarine by secondary embryogenesis. Plant Cell Rep. 1990, 9, 280-284. [CrossRef] [PubMed]

6. Scorza, R.; Morgens, P.H.; Cordts, J.M.; Mante, S.; Callahan, A.M. Agrobacterium-mediated transformation of peach (Prunus persica L. batsch) leaf segments, immature embryos, and long-term embryogenic callus. Vitr. Cell. Dev. Biol. 1990, 26, 829-834.

7. Smigocki, A.C.; Hammerschlag, F.A. Regeneration of Plants from Peach Embryo Cells Infected with a Shooty Mutant Strain of Agrobacterium. J. Am. Soc. Hortic. Sci. 1991, 116, 1092-1097. [CrossRef] 
8. Pérez-Clemente, R.M.; Pérez-Sanjuán, A.; García-Férriz, L.; Beltrán, J.-P.; Cañas, L.A. Transgenic peach plants (Prunus persica L.) produced by genetic transformation of embryo sections using the green fluorescent protein (GFP) as an in vivo marker. Mol. Breed. 2005, 14, 419-427. [CrossRef]

9. Sabbadini, S.; Pandolfini, T.; Girolomini, L.; Molesini, B.; Navacchi, O. Peach (Prunus persica L.) BT-Agrobacterium Protocols: Volume 2; Wang, K., Ed.; Springer: New York, NY, USA, 2015; pp. $205-215$. ISBN 978-1-4939-1658-0.

10. Gentile, A.; Monticelli, S.; Damiano, C. Adventitious shoot regeneration in peach [Prunus persica (L.) Batsch]. Plant Cell Rep. 2002, 20, 1011-1016. [CrossRef]

11. Zhou, H.; Li, M.; Zhao, X.; Fan, X.; Guo, A. Plant regeneration from in vitro leaves of the peach rootstock 'Nemaguard' (Prunus persica $\times$ P. davidiana). Plant Cell Tissue Organ Cult. 2010, 101, 79-87. [CrossRef]

12. San, B.; Li, Z.; Hu, Q.; Reighard, G.L.; Luo, H. Adventitious shoot regeneration from in vitro cultured leaf explants of peach rootstock Guardian ${ }^{\circledR}$ is significantly enhanced by silver thiosulfate. Plant Cell Tissue Organ Cult. 2015, 120, 757-765. [CrossRef]

13. Zong, X.; Denler, B.J.; Danial, G.H.; Chang, Y.; Song, G. Adventitious Shoot Regeneration and Agrobacterium tumefaciens-mediated Transient Transformation of Almond $\times$ Peach Hybrid Rootstock 'Hansen 536'. Hortscience 2019, 54, 936-940. [CrossRef]

14. Biddington, N.L. The influence of ethylene in plant tissue culture. Plant Growth Regul. 1992, 11, $173-187$. [CrossRef]

15. Veen, H.; van de Geijn, S.C. Mobility and ionic form of silver as related to longevity of cut carnations. Planta 1978, 140, 93-96. [CrossRef] [PubMed]

16. Burgos, L.; Alburquerque, N. Ethylene inhibitors and low kanamycin concentrations improve adventitious regeneration from apricot leaves. Plant Cell Rep. 2003, 21, 1167-1174. [CrossRef] [PubMed]

17. Liu, X.; Pijut, P.M. Plant regeneration from in vitro leaves of mature black cherry (Prunus serotina). Plant Cell Tissue Organ Cult. 2008, 94, 113-123. [CrossRef]

18. Petri, C.; Scorza, R. Factors affecting adventitious regeneration from in vitro leaf explants of 'Improved French' plum, the most important dried plum cultivar in the USA. Ann. Appl. Biol. 2010, 156, 79-89. [CrossRef]

19. Byrne, D.H.; Raseira, M.B.; Bassi, D.; Piagnani, M.C.; Gasic, K.; Reighard, G.L.; Moreno, M.A.; Pérez, S. Peach BT_Fruit Breeding; Badenes, M.L., Byrne, D.H., Eds.; Springer: Boston, MA, USA, 2012; pp. 505-569. ISBN 978-1-4419-0763-9.

20. Connell, J.H.; Buchner, R.; Duncan, R.; Edstrom, J.; Micke, W.; Verdegaal, P.; Viveros, M. Evaluation of Potential Rootstocks for California Almonds. In Proceedings of the Acta Horticulturae; International Society for Horticultural Science (ISHS): Leuven, Belgium, 2002; pp. 45-52.

21. Pinochet, J. 'Greenpac', a New Peach Hybrid Rootstock Adapted to Mediterranean Conditions. HortScience 2009, 44, 1456-1457. [CrossRef]

22. Kester, D.E.; Asay, R.N. "Hansen 2168" and "Hansen 536": Two new Prunus rootstock clones. HortScience 1986, 21, 331-332.

23. Felipe, A.J.; Gómez-Aparisi, J.; Socías, R.; Carrera, M. The Almond X Peach Hybrid Rootstocks Breeding Program At Zaragoza (Spain). In Proceedings of the Acta Horticulturae; International Society for Horticultural Science (ISHS): Leuven, Belgium, 1997; pp. 259-262.

24. Declerck, V.; Korban, S.S. Influence of growth regulators and carbon sources on callus induction, growth and morphogenesis from leaf tissues of peach (Prunus persica L. Batsch). J. Hortic. Sci. 1996, 71, 49-55. [CrossRef]

25. Escalettes, V.; Dosba, F. In vitro adventitious shoot regeneration from leaves of Prunus spp. Plant Sci. 1993, 90, 201-209. [CrossRef]

26. Miguel, C.M.; Druart, P.; Oliveira, M.M. Shoot regeneration from adventitious buds induced on juvenile and adult almond (Prunus dulcis mill.) explants. Vitr. Cell. Dev. Biol. Plant 1996, 32, 148-153. [CrossRef]

27. Pérez-Tornero, O.; Egea, J.; Vanoostende, A.; Burgos, L. Assessment of factors affecting adventitious shoot regeneration from in vitro cultured leaves of apricot. Plant Sci. 2000, 158, 61-70. [CrossRef]

28. Mazumdar, P.; Basu, A.; Paul, A.; Mahanta, C.; Sahoo, L. Age and orientation of the cotyledonary leaf explants determine the efficiency of de novo plant regeneration and Agrobacterium tumefaciens-mediated transformation in Jatropha curcas L. S. Afr. J. Bot. 2010, 76, 337-344. [CrossRef] 
29. Cardoso, J.C.; Habermann, G. Adventitious shoot induction from leaf segments in Anthurium andreanum is affected by age of explant, leaf orientation and plant growth regulator. Hortic. Environ. Biotechnol. 2014, 55, 56-62. [CrossRef]

30. James, D.J.; Passey, A.J.; Rugini, E. Factors Affecting High Frequency Plant Regeneration from Apple Leaf Tissues Cultured in vitro. J. Plant Physiol. 1988, 132, 148-154. [CrossRef]

31. Bhatia, P.; Ashwath, N.; Midmore, D.J. Effects of genotype, explant orientation, and wounding on shoot regeneration in tomato. Vitr. Cell. Dev. Biol. Plant 2005, 41, 457-464. [CrossRef]

32. Meng, R.; Chen, T.H.H.; Finn, C.E.; Li, Y. Improving in vitro plant regeneration from leaf and petiole explants of "Marion" blackberry. HortScience 2004, 39, 316-320. [CrossRef]

33. Sarwar, M.; Skirvin, R.M. Effect of thidiazuron and 6-benzylaminopurine on adventitious shoot regeneration from leaves of three strains of "McIntosh" apple (Malus X domestica Borkh.) in vitro. Sci. Hortic. (Amsterdam) 1997, 68, 95-100. [CrossRef]

34. Chi, G.-L.; Barfield, D.G.; Sim, G.-E.; Pua, E.-C. Effect of AgNO3 and aminoethoxyvinylglycine on in vitro shoot and root organogenesis from seedling explants of recalcitrant Brassica genotypes. Plant Cell Rep. 1990, 9, 195-198. [CrossRef]

35. Kumar, V.; Parvatam, G.; Ravishankar, G.A. AgNO3: A potential regulator of ethylene activity and plant growth modulator. Electron. J. Biotechnol. 2009, 12, 8-9. [CrossRef]

36. Möllers, C.; Zhangm, S.; Wenzel, G. The Influence of Silver Thiosulfate on Potato Protoplast Cultures. Plant Breed. 1992, 108, 12-18. [CrossRef]

37. Trujillo-Moya, C.; Gisbert, C. The influence of ethylene and ethylene modulators on shoot organogenesis in tomato. Plant Cell Tissue Organ Cult. 2012, 111, 41-48. [CrossRef]

38. Dimasi-Theriou, K.; Economou, A.S. Ethylene enhances shoot formation in cultures of the peach rootstock GF-677 (Prunus persica $\times$ P. amygdalus). Plant Cell Rep. 1995, 15, 87-90. [CrossRef]

39. Nakano, M.; Mii, M. Antibiotics Stimulate Somatic Embryogenesis without Plant Growth in Several Dianthus Cultivars. J. Plant Physiol. 1993, 141, 721-725. [CrossRef]

40. Dai, W.; Castillo, C. Factors Affecting Plant Regeneration from Leaf Tissues of Buddleia Species. HortScience 2007, 42, 1670-1673. [CrossRef]

41. Yu, Y.; Wei, Z.-M. Influences of cefotaxime and carbenicillin on plant regeneration from wheat mature embryos. Biol. Plant 2008, 52, 553-556. [CrossRef]

42. Bosela, M.J. Effects of $\beta$-lactam antibiotics, auxins, and cytokinins on shoot regeneration from callus cultures of two hybrid aspens, Populustremuloides $\times$ P. tremula and P. xcanescens $\times$ P. gradidentata. Plant Cell Tissue Organ Cult. 2009, 98, 249-261. [CrossRef]

43. Silvestri, C.; Cristofori, V.; Ceccarelli, M.; Caceres, M.E.; Escribà-Lacuesta, J.; Rugini, E. Adventitious shoot organogenesis from leaf and petiole explants of European hazelnut. Plant Cell Tissue Organ Cult. 2016, 126, 59-65. [CrossRef]

44. Orlikowska, T.K.; Cranston, H.J.; Dyer, W.E. Factors influencing Agrobacterium tumefaciens-mediated transformation and regeneration of the safflower cultivar 'centennial'. Plant Cell Tissue Organ Cult. 1995, 40, 85-91. [CrossRef]

45. Hammerschlag, F.A.; Zimmerman, R.H.; Yadava, U.L.; Hunsucker, S.; Gercheva, P. Effect of Antibiotics and Exposure to an Acidified Medium on the Elimination of Agrobacterium tumefaciens from Apple Leaf Explants and on Shoot Regeneration. J. Am. Soc. Hortic. Sci. JASHS 1997, 122, 758-763. [CrossRef]

46. Yu, T.A.; Yeh, S.D.; Yang, J.S. Effects of carbenicillin and cefotaxime on callus growth and somatic embryogenesis from adventitious roots of papaya. Bot. Bull. Acad. Sin. 2001, 42, 281-286.

47. Shehata, A.M.; Wannarat, W.; Skirvin, R.M.; Norton, M.A. The dual role of carbenicillin in shoot regeneration and somatic embryogenesis of horseradish (Armoracia rusticana) in vitro. Plant Cell Tissue Organ Cult. 2010, 102, 397-402. [CrossRef]

48. Holford, P.; Newbury, H.J. The effects of antibiotics and their breakdown products on the in vitro growth of Antirrhinum majus. Plant Cell Rep. 1992, 11, 93-96. [CrossRef] [PubMed]

49. Nauerby, B.; Billing, K.; Wyndaele, R. Influence of the antibiotic timentin on plant regeneration compared to carbenicillin and cefotaxime in concentrations suitable for elimination of Agrobacterium tumefaciens. Plant Sci. 1997, 123, 169-177. [CrossRef]

50. Borrelli, G.M.; Di Fonzo, N.; Lupotto, E. Effect of Cefotaxime on Callus Culture and Plant Regeneration in Durum Wheat. J. Plant Physiol. 1992, 140, 372-374. [CrossRef] 
51. Yepes, L.M.; Aldwinekle, H.S. Factors that effect leaf regeneration efficiency in apple, and effect of antibiotics in morphogenesis. Plant Cell Tissue Organ Cult. 1994, 37, 257-269.

52. Sarma, K.S.; Evans, N.E.; Selby, C. Effect of carbenicillin and cefotaxime on somatic embryogenesis of Sitka spruce (Picea sitchensis (Bong.) Carr.). J. Exp. Bot. 1995, 46, 1779-1781. [CrossRef]

53. Grzebelus, E.; Skop, L. Effect of $\beta$-lactam antibiotics on plant regeneration in carrot protoplast cultures. Vitr. Cell. Dev. Biol. Plant 2014, 50, 568-575. [CrossRef]

54. Sujana, P.; Naidu, C.V. Influence of Bavistin, Cefotaxime, Kanamycin and Silver Thiosulphate on Plant Regeneration of Mentha piperita (L.)—An Important Multipurpose Medicinal Plant. J. Phytol. 2011, 3, 36-40.

55. Tambarussi, E.V.; Rogalski, M.; Nogueira, F.T.S.; Brondani, G.E.; De Martin, V.F.; Carrer, H. Influence of antibiotics on indirect organogenesis of Teak. Ann. For. Res. 2015, 58, 177-183. [CrossRef]

56. Rugini, E.; Caricato, G. Somatic embryogenesis and plant recovery from mature tissues of olive cultivars (Olea europaea L.) "canino" and "moraiolo". Plant Cell Rep. 1995, 14, 257-260. [CrossRef] [PubMed]

57. Lloyd, G.; McCown, B. Commercially-feasible micropropagation of mountain laurel, Kalmia latifolia, by use of shoot-tip culture. Commer. Feasible Micropropag. Mt. Laurel Kalmia Latifolia Use Shoot Tip Cult. 1980, 30, 421-427.

(C) 2020 by the authors. Licensee MDPI, Basel, Switzerland. This article is an open access article distributed under the terms and conditions of the Creative Commons Attribution (CC BY) license (http://creativecommons.org/licenses/by/4.0/). 